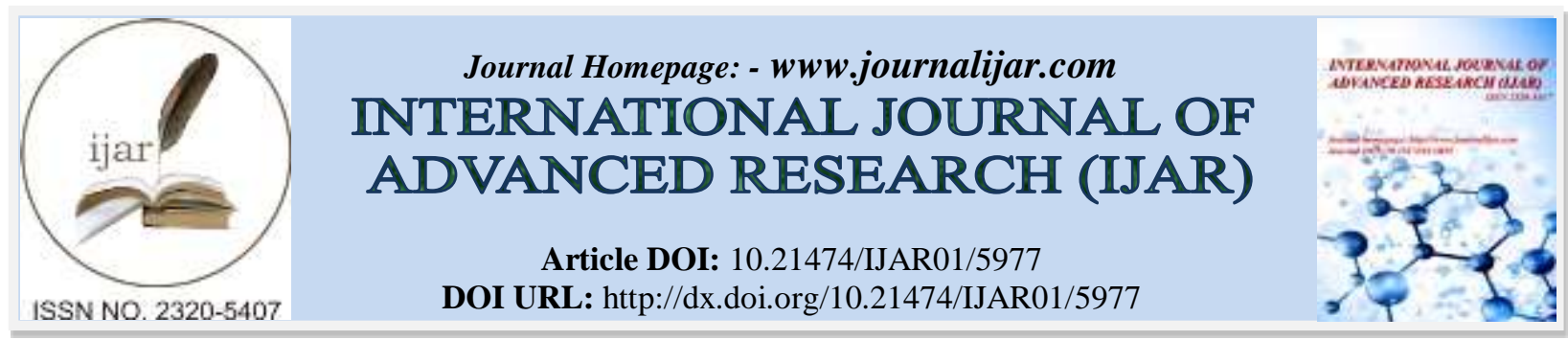

RESEARCH ARTICLE

\title{
BUSINESS SUSTAINABILITY MODEL FOR LOGISTICS MANAGEMENT IN TRAVEL AGENCIES.
}

\section{Neyfe Sablón Cossío ${ }^{1}$, Yeidys Cuétara Hernández ${ }^{2}$, Evis Dieguez Matellán ${ }^{3}$ and Leonardo Manuel Cuétara Sánchez ${ }^{4}$.}

1. North Technical University, Ibarra, Ecuador. Career of Industrial Engeniering.

2. Matanzas of University, Matanzas, Cuba. Career of Industrial Engeniering.

3. Agricultural Polytechnic Superior School of Manabí, Ecuador. Career de Public Administration.

4. Equinoctial Technologic University, Quito, Ecuador. Tourism Observatory Department.

\section{Manuscript Info}

Manuscript History

Received: 05 October 2017

Final Accepted: 07 November 2017

Published: December 2017

Key words:-

Sustainability model, logistics management, Travel agencies.

\section{Abstract}

The local community in touristic destinations, gives more relevance to the responsible actions done by touristic enterprises to mitigate the environmental and social impacts that they have on the touristic area. Documentary research in scientific literature, indicates the recognition and importance of logistics management, as a process of necessary support to ensure the provision of tourist services operations. However, the business practice in tourist activity shows poor knowledge that managers have on the subject of study. Besides, it shows the nonexistence of a specific model that allows a logistic evaluation of the portfolio of products and services in travel agencies. As the objective of the research, it is described a business sustainability model for logistics management with a process approach for products and services in Travel Agencies. The methodology assumed in the study, corresponds to the philosophy of management by processes, (useful and updated approach to address the issue of the subject of study), through the combination of quantitative and qualitative methods for collecting information; group work techniques, scales of measurement, tools and procedures for statistical analysis and multi-criteria modeling procedures. As a result of the investigation, it proposes a theoretical model, its corresponding methodological procedure and a set of management indicators, for the evaluation of the business sustainability from the logistic management in travel agencies like business organization object of study.

Copy Right, IJAR, 2017,. All rights reserved.

\section{Introduction:}

Tourism is a service which requires a logistics management adjusted to the needs of customers (tourists) and at the same time it is a tool that contributes to the competitiveness of the destination (Garcia, López, Iniesta, González, \& Ávila, 2016). This corresponds to the objective of the logistics system, offer a high level of service (González, 2016), at the time, place and price the customers wants it (Ponce, 2003). Simultaneously, it is a backing for basic, support and ancillary services in the tourism sector (Kandampully \& Promsivapallop, 2006; Ortega, Rodríguez, \& Lévy, 2008). Because of the expertise that is needed for this type of service, logistics human potential must have a focus on the customer (Ramallo, 2015), and holistic approach in relation to materials, informational, financial flows 
and knowledge comprehensively to the needs of the consumer (Frederickson \& Johansson, 2009). Adds the concept of (Thai, 2013) which refers that logistics processes conducive to the quality of service. Finally, it is convenient to point out the relationship between sustainability and logistics, which aims to improve the economic benefits and mitigate the impacts on the environment and society, are topics of debate today as points out (Kutch, 2015); as well as, the article referred to the contribution of logistics to the sustainable development of (Ballesteros et.al., 2009).

At the international level, the World Bank records and defines the logistics performance index. The index of reference mentioned is composed of several components, namely: customs, infrastructure, quality of service, waiting times, international shipments, and traceability of the goods. The indicator allows to make a ranking of 155 countries based on the value of the pattern of the meter, using a scale where one is the lowest and 5 is the best. Ecuador is located at place 91 , with a metric of 2.78 in 2016 so the logistics performance index is low, although it increased by 0.18 of 2.6 in 2007 (The World Bank, 2017).

Nowadays travel agencies are contextualized in a complicated and difficult scenario, due to the changing situation and the main function of this type of intermediaries (Al-Weshah, Alnsour, Al-Hyari, Alhammad, \& Algharabat, 2013; Montero Muradas \& Oreja Rodríguez, 2010), which is the interrelation between: tourist, destinations, hotels, inns, airports; where new information technologies (Liu, Pu, Guan, \& Yang, 2016), influence the projection of the logistics system. The integration of the Internet in the travel and tourism industry is a challenge for the traditional role of travel agencies(Law, Law, \& Wai, 2002; Pirolli, 2016). Travel agencies are classified in retail and wholesale (Hernández \& Hernández, 1998), depending on the volume and quantity of the tourist package they offer (in this research the wholesaler is studied).

Nowadays, tourism is an element of great importance for the social, economic and cultural growth of a country, due to the diversity of activities that are generated, favoring the continuous and periodic growth of society. It is a tool that produces currencies, channeling investments to promote and expand the general economy of a country; in the same way it becomes a supplier of diversified jobs through a very low investment, compared to other areas of the economy, thus forming a convenient balance of payments and, more importantly, growth and economic development in Communities (Cuétara, 2017). The tourist potential in Ecuador is based on its high diversity in terms of culture, landscapes, historical sites and natural wealth. According to a study on Ecuador's competitiveness, the country's strength in the international tourism market lies on its natural heritage and the cultural values of its host communities. In this sense, the country's natural and cultural diversity plays a decisive role in the sustainability of tourism and the economic benefits associated with it. The qualitative and quantitative relevance of tourism in Ecuador supports the perception of a great potential in the sector that can be used in an integral way. In Ecuador, tourism has a variety of tourist offer, from general circuits, sun and beach, ecotourism, bird watching, great adventure, sports, Cultural, Rural, conventions and congresses and incentives (Carvache, Torres, \& Carvache, 2017).

The aim of this article is the description of a business sustainability model and methodological procedure, for the logistics management with a process approach of the portfolio of products and services in Travel Agencies located in tourist destinations of Cuba and Ecuador respectively.

Analysis of the previous models for logistics management in business organizations:

With regard to the review of the literature on the formulation of logistical management models, the following cited by (García et.al, 2015): Model of the Secretariat of Economy of Mexico, reference model of supply chain operations (SCOR- Model: Supply Chain Council of North América). In the literature there are models referred to the logistics management, quoted by (Cuétara, 2010) among which distinguished: Model of the value-added chain (Porter, 1985); model of assessment of the production organization level (Suárez, 1996); Model of assessment of the production system (Gómez y Acevedo, 1997) among others referenced in the specialized literature on the topic.

Other models related to the management of the corporate social responsibility associated with different productive activities and services, correspond to the following case studies: Corporate social responsibility model for companies Laboratories of Retinas S.A.S.; analysis and proposal for a model of corporate social responsibility management case: Ecuadorian companies committed to Corporate Social Responsibility (Espinosa, 2010); management model of corporate social responsibility for companies (Ramírez, 2011); corporate social responsibility model in a consulting company through the implementation of the social marketing (Geraldino et. al ,2012); Corporate social responsibility model for SMEs construction company Araucana (Ruiz, 2013); planning considerations of food products in a commercial supply chain (Sablón et.al., 2013); model SCOR (Supply Chain 
Operations Reference Model) applied to the supply chain of companies in the trade sector (Coavas and Amézquita, 2011); Optimization models for sustainable design of multiple product recycling supply chains (Feitó, Cespón and Rubio,(2016); among other publications of theoretical and practical contributions related to the subject of study.

From these theoretical and practical models, it is defined two decades ago another model of diagnosis of the logistics with holistic philosophy, due to its application in a total of 185 companies in Latin America and the Caribbean and comprises thirteen modules (variables), which is Referred to as Reference Model in the specialized bibliography. This model includes different factors for the improvement of the competitiveness, review for the training of staff and the direction of transformation processes in the companies toward international standards, in addition, constitutes a pattern for companies to establish where its main weaknesses and strengths are and where are the main opportunities and barriers that provides the environment, which allows for the devising and implementation of a strategic plan for the development of logistics in coordination with the business strategy.

The main deficiencies identified from the conceptual point of view and their applicability to the revision of the models of logistics management, as well as corporate social responsibility consulted, correspond with: very few models of the mentioned in the specialist literature, consider the logistics system as a single, coordinated and balanced system; they only use the general method of troubleshooting; describe a simple mathematical modeling, that does not guarantee the representation of the complexity inherent in all the logistics system; does not allow to simultaneously evaluate the impact of the decisions on the internal structure of the organization and the results, as a way of achieving an integrated and coherent solution with the objectives of the logistics system, the nonincorporation of the perspective of the process approach, nor are the main measurement variables for the evaluation of the logistics activity of the processes in tourism companies, specially, from the sustainability paradigm and the multidimensionality, the portfolio of tourism products and services respectively.

\section{Business Sustainability model for logistics management in travel agencies:}

For the description of the business sustainability model for the logistics management in Travel Agencies, two different proposals has been reviewed from the scientific literature: the proposal of a reference model for the logistics of excellence (Acevedo, 2008) and a second proposal concerning the corporate sustainability model of Epstein, Alberto and Mantilla (2009), which incorporates the social, environmental and financial dimensions of sustainability as its basis. The model points out the orientations of the behavior of corporate sustainability, the operations that managers can take to complete that performance and the consequences that such operations have on the cooperative performance of environmental, social and financial support, it also includes the presentation of both internal and external reports, together with the broader set of measures, as well as, provides the procedures for the linkage with the financial economic performance, social concerns, environmental and ethical matters, in addition to recognizing the relevance of the problems of social leadership and other compared to overall corporate performance. It should be noted in the same way, detailing the structure of the corporate accountability that can be used as the basis for the implementation of the sustainability strategy.

In the corporate sustainability model of Epstein, Alberto and Mantilla (2009), describes the inputs of the model, which contain the external context (regulatory, geographic), internal (mission, strategy, structure, systems), business (sector of industry, customers, product), human talent and financial resources. The component inputs, sorted the decisions of managers and processes that the organization undertakes to improve sustainability. Following the evaluation of the inputs and its possible effects on the improvement of sustainability, the proposal of strategies, structure, systems, programs and actions for sustainability, which identifies different impacts: corporate financial costs and benefits of the actions, social and environmental impact and final financial impact. With regard to the financial performance, managers can develop the appropriate processes to improve sustainability, on the basis of the strategies, structure of the organization and the proposal of actions, programs and systems in this direction.

A fundamental aspect of the model of corporate sustainability, is the distinction between intermediate results (outputs and outcomes) its financial implications. We distinguish processes that have immediate and identifiable costs and benefits that affect long-term corporate financial performance. It is displayed in the same way, the impact of the different inputs and processes in the performance of sustainability, as well as describe, as the corporate financial performance is impacted by the reactions of the stakeholder compared to the performance of corporate sustainability. 
Therefore the outputs-Intermediate results, such as the social and environmental performance, public image, hiring employees, reactions of customers and market share, must be monitored to determine the effectiveness of the sustainability management practices. The factors leading to the success of sustainability are described in (Epstein, Alberto and Mantilla, 2009).

Finally, it is necessary to highlight among the main contributions referred to the problem of research: the proposal of integration of the functions of counseling, mediation, producer and operations; with the main economic-financial processes, human talent, operations, marketing, assistance to representations and management, supported by the process approach, as well as, the discrimination of a set of management measurers, relating to the processes identified that will allow the evaluation of the sustainable logistics management in each of the core modules that distinguish the operation and development of Travel Agencies in the tourism sector.

\section{Methods and procedures:-}

Description of a business sustainability model for logistics management of the portfolio of products and services from the perspective of process approach in Travel Agencies.:-

From the analysis, it allows the description of business sustainability model for the logistics management of the portfolio of products and services (from the perspective of the process approach). The design of this management model has as main background work the reference model for logistics excellence (Acevedo, 2008), and the model of business sustainability (Epstein, Alberto and Mantilla, 2009). In its content incorporates the objectives of the logistics management for this type of tourist service with no record in the literature review carried out, in addition, identify the processes Travel Agency has associated with each module (corresponding to the preceding analysis).

The business sustainability model for the logistics management of the portfolio of products and services from the perspective of the process approach in travel agencies is conceived with a systemic and integrative approach. The systemic approach of this model is determined because the Travel Agency demand a flow of inputs as established in the business sustainability model, with their respective adjustments according to the type of subject of study (tourism legislation, natural resources and tourist attractions, human talent; equipment, technology and financial resources, service suppliers), necessary to provide the service to the customers: sales of tours and excursions, services of representations, transfer and incentive groups and special programs. It also guarantees the organization of congresses, VIP services, and assistance to groups in familiarization trips, individual services specialized guides, Reservation and confirmation of airline tickets, processing of passports, visas, rent a car, multi-destination offers and service facilities.

At the same time, it generates a flow of outputs of cultural, social, economic and environmental impact on the host community and the tourist area where the offer of products and services is developed. The proposal of the business Sustainability model for logistics management in travel agencies is described from the conceptual point of view. The model process approach is based on: any activity, or set of activities linked to each other, that uses resources and controls to transform input elements (specifications, resources, information, services) into results (other Information, services) may be seen as a process. The results of a process must have an added value compared to the entries and can directly constitute input elements of the next process. All the activities of the Organization, from the planning of the purchases to the customer service to complaints, can and should be considered as processes. In order to operate effectively, organizations need to identify and manage numerous interrelated and interacting processes. The identification and systematic management of the processes carried out in the organization and in particular the interactions between such processes are known as process -based approach (ISO 9001:2015).

Process management is defined as the way to manage an interrelated system of business processes in place of the traditional function based management. It is considered a way to achieve customer satisfaction; it also allows to optimize the added value contribution and be a member of the quality management. It is necessary, then, to clarify the concept of process, (Park, Kim, Kwon, \& Yu, 2017), it is the "logical and ordered sequence of repetitive activities that are carried out in the Organization by a person, group or department, with the ability to transform inputs (inputs) into outputs or results (outputs) to a recipient (within or outside the company that have requested it and who are the customers of each process) with an added value".

Every business organization is a system, each process is a system functions and functions or activities have been grouped in departments or functional areas. 
Process management is to manage comprehensively each of the transactions or processes that the company performs. The following processes have been identified in the travel agency: design, marketing, organization, travel operation and touristic products related to the production function, reservation, distribution and sale, with the mediator function. Finally, the information and global booking system with the advisory function.

In today's globalized world, it is critical to get quickly to customer with the products and services that they demand with the desired quality and with minimal costs compared to a growing competence and a radical expansion of the geography of the trade market and a provisioning under the influence of the globalization of the economy. In this situation, the logistical approach in business management is an imperative need to achieve competitiveness in today's environment. That is why it is defined that the logistics has turned into the new factor of competitive differentiation. To accept this challenge, an accelerated development of logistics in the company is necessary in the field of its philosophy, structure, concepts and techniques.

The main provisions of the management philosophy associated with the logistics approach are the following: permanent customer satisfaction (Anjum, Xiuchun, Abbas, Shuguang, \& McMillan, 2017; Kandampully \& Suhartanto, 2003), just in time: produce and manage what is demanded at every moment (Boysen, Briskorn, \& Emde, 2016), manage the business as an integrated flow of materials, information and values (Ivanov, Sokolov, \& Raguinia, 2014), working with small batches, integration with customers and suppliers (Chiang, Chen, \& Wu, 2015), constant fight to decrease the stocks (Govindan, 2013), process management (Chen, 2014), wide application of selfcontrol and self-management and wide application of teamwork.

The integration of these precepts is a philosophy for the logistics management of the Tourist Organization, not as an isolated, but integrated management philosophy as a whole approach.

The logistic approach (specifying in the travel agency) is manifested from the customer service focus -this content is identified with stakeholder reactions (Epstein, Alberto and Mantilla, 2009) as described in the corporate sustainability model-and this should be focused on your satisfaction, personalization, anticipating customer needs and do exactly what the customer demands according to the requirements and regulations established in the negotiation with the service providers and local community. To achieve an integration between the Travel Agency and logistics management in the business sustainability model for the logistics management of the product and service portfolio, Each process that the agency has is associated with the module that corresponds to it and from there conduct the assessment of the behavior of each of the processes of the business organization in the achievement of better logistics management.

In the scientific literature review regarding logistics management in the business sector, identifies a description of different modules, as well as its relationship with the travel agency processes and the components of the business model sustainability to which it relates. In the article cited as a reference model for logistics of Excellence (Acevedo, 2008) to diagnose logistics management, thirteen modules are detailed, of which a total of nine modules have been selected, taking into account the type of business organization, besides, to make an adequacy to each one of the names that identify them, according to the terms that are used today in the tourism industry.

In order to achieve the necessary systematization of the components of the business sustainability model with the logistics management in travel agencies, it is considered relevant to describe this behavior from the input component, which includes the following modules: 01. Logistics concept of the tourist organization (management process), 02. Organization and management (process of marketing and operations), 03. Information technology (appears in all the processes described for the travel agency) 04. Software system (similar behavior to the previous module), 06. Human Capital (Human resources process), 08. Environmental barriers (marketing process), 09 Responsible action (management process) within this perspective, the modules that are particularized correspond to the output component of the business sustainability model for the logistics management of the product and services portfolio, and include: 05. Supply chain integration (process of travel operations and touristic products, marketing and assistance and representation), 07. Management of logistics yields (marketing and economic-financial process), as well as 09. Responsible action (management process) whose conceptual and practical argument is specified in (Cuétara, 2010).

The previous analysis implies that the travel agency demands a flow of human, logistical and environmental inputs (underwriting business, supplies, product and service portfolios, demand characterization, Operational costs and 
expenses, market research, description of the elements of the contact staff, external customers and service providers), necessary for offering to the clients optional activities, excursions, circuits, transfer operations of transfer Inter hotels. Likewise, it generates a flow of outputs (measurement of results indicators related to the logistics management, considering the strategic and operational processes identified for a travel agency (management, human resources, operations, Economic-Financial, assistance and representation and marketing), subsequently proceeds to the evaluation of impacts of the travel agency activity from the social, environmental, economic and technological dimension), from the business organization itself, and from the segments selected for the information gathering, including internal and external customer, service providers and the local community itself. In Figure 1, the theoretical and operational design of the sustainability model for logistics management is exposed, to study in an integral way, the issue of sustainability and logistics in travel agencies located in tourist destination of sun and beach, as pictured below.

Figure 1:- Description of the sustainability model for the logistics management of product and service portfolio in travel agencies.

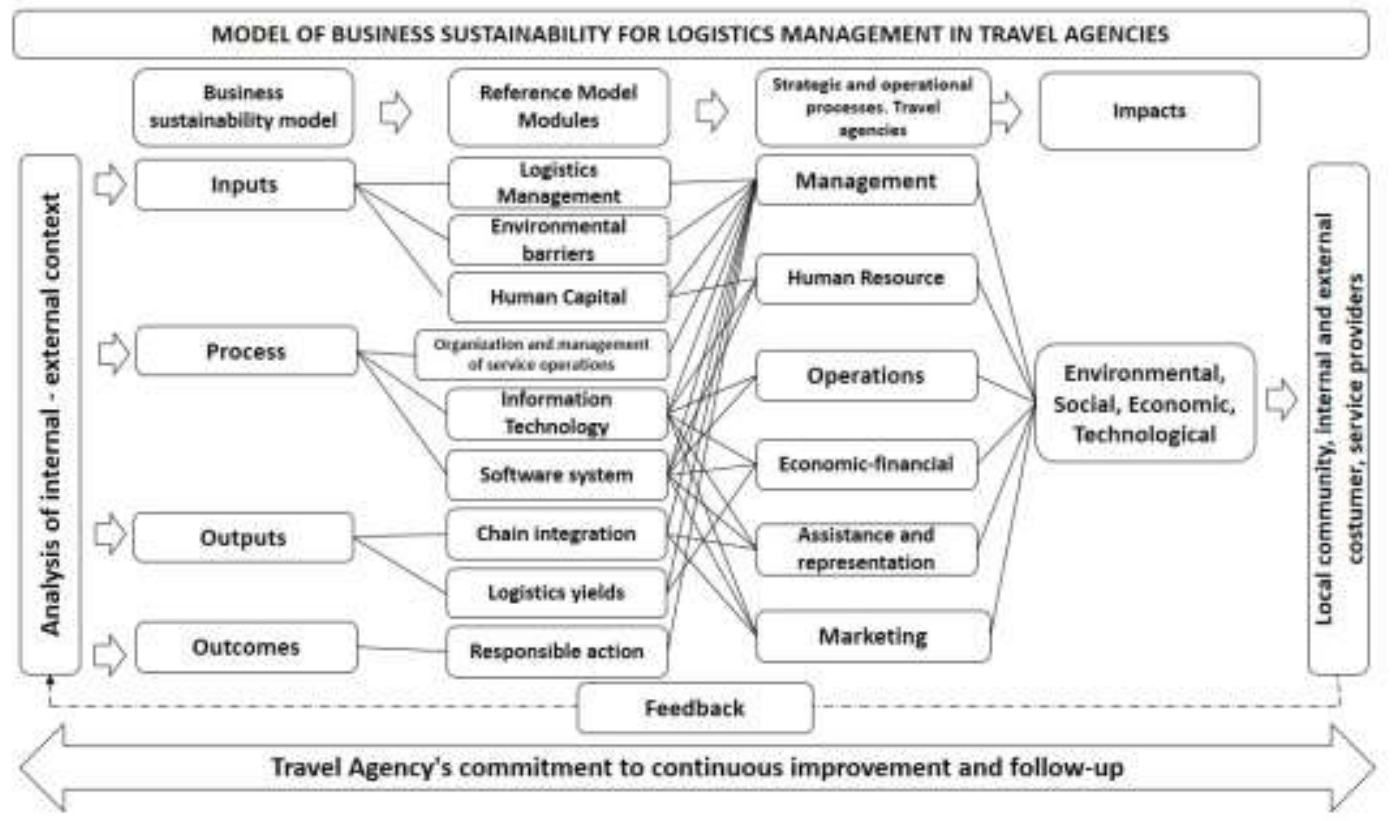

Source: Adapted from Cuétara, (2010).

The methodological procedure that has been designed for the implementation of the sustainability model for logistics management is distinguished from the proposals analyzed in the reference literature.

The methodological procedure that has been designed for the implementation of the sustainability model for logistics management is distinguished from the proposals analyzed in the preceding reference literature. At the same time, it has originality and scientific novelty, considering that, in its conception prevails the analysis of the travel agency with a process and logistic approach for each of the modules identified in the research; It presents a working procedure with expert judgments for the selection of measuring process indicators for the evaluation of logistics management by Kendall's coefficient of concordance and consensus, Fuller's Multiattribute method to determine the priorities of each of the modules (Frías, et al., 2008); the structuring of a procedure for the diagnosis of logistics management, as well as, the preparation of measuring instruments of scale LIKERT, recommended by different authors in satisfaction surveys of internal, external customer, Service providers and local community; besides, the item-Total correlation test, the determination of the reliability of the measuring scale proposal using the Cronbach's alpha coefficient, the test of content and construct validity (Cuétara, 2010).

Therefore, it is detailed each of the phases, stages, quantitative and qualitative research methods, as well as the main sources of information which make up the theoretical scheme of a methodological procedure for the implementation of the sustainability model for Logistics Management in Travel Agencies, Chart 1. 
Chart 1: Theoretical and practical outline of the methodological procedure.

\begin{tabular}{|c|c|c|c|}
\hline Phases & Stages & Reseach methods & Information sources \\
\hline $\begin{array}{l}\text { Phase I: } \\
\text { Description of a } \\
\text { business } \\
\text { sustainability } \\
\text { model for logistics } \\
\text { management }\end{array}$ & $\begin{array}{l}\text { Stage I.1: Search, localization and } \\
\text { selection of the literature on the } \\
\text { proposal of logistics management } \\
\text { model } \\
\text { Stage I. } 2 \text { Processing and analysis } \\
\text { of the information of the logistic } \\
\text { management models in business } \\
\text { organizations }\end{array}$ & $\begin{array}{l}\text { Exploratory research, docum } \\
\text { ent analysis and literature rev } \\
\text { iew, } \\
\text { search on web sites, scientific } \\
\text { journals, papers and research } \\
\text { projects, among others. }\end{array}$ & $\begin{array}{l}\text { Scientific } \\
\text { indexed in SCOPUS } \\
\text { and web of science } \\
\text { Google } \\
\text { Database electronic } \\
\text { repositories of higher } \\
\text { education institutions }\end{array}$ \\
\hline $\begin{array}{l}\text { Phase II: Design of } \\
\text { a procedure for } \\
\text { diagnosing logistics } \\
\text { management in } \\
\text { travel agency }\end{array}$ & $\begin{array}{l}\text { Stage II.1: Analysis of previous } \\
\text { methodological procedures for } \\
\text { the diagnosis of logistics } \\
\text { management } \\
\text { Stage II.2: Selection of the } \\
\text { sample and work team with } \\
\text { qualified } \\
\text { Stage II. 3: Description of the } \\
\text { functions of the travel agency } \\
\text { Stage II. 4: Design of data } \\
\text { collection and analysis } \\
\text { instruments }\end{array}$ & $\begin{array}{l}\text { Document analysis, } \\
\text { information gathering, group } \\
\text { work technique, expert } \\
\text { method, consensus method, } \\
\text { survey design and Likert-type } \\
\text { scales }\end{array}$ & $\begin{array}{l}\text { Scientific } \\
\text { indexed in SCOPUS } \\
\text { and web of science } \\
\text { Google } \\
\text { Database electronic } \\
\text { repositories of higher } \\
\text { education institutions }\end{array}$ \\
\hline $\begin{array}{l}\text { Phase III: } \\
\text { Implementation of } \\
\text { the methodological } \\
\text { procedure for the } \\
\text { diagnosis of } \\
\text { logistics } \\
\text { management in } \\
\text { travel agency }\end{array}$ & $\begin{array}{l}\text { Stage III. 1: Characterization of } \\
\text { the processes of the travel agency } \\
\text { Stage III. 2: Characterization of } \\
\text { the logistics approach in the } \\
\text { travel agency } \\
\text { Stage III. } 3 \text { Characterization of } \\
\text { the supply of products and } \\
\text { services, the demand and analysis } \\
\text { of the market }\end{array}$ & $\begin{array}{l}\text { Document analysis, } \\
\text { questionnaire design, data } \\
\text { collection and analysis of } \\
\text { product and service portfolio, } \\
\text { demand behavior, } \\
\text { statistical methods }\end{array}$ & $\begin{array}{l}\text { Information gathered } \\
\text { from the strategic } \\
\text { planning documents, } \\
\text { semi-annual technical, } \\
\text { economic and financial } \\
\text { information, indicators } \\
\text { from the marketing plan } \\
\text { provided by the travel } \\
\text { agency }\end{array}$ \\
\hline $\begin{array}{lr}\text { Phase } & \text { IV: } \\
\text { Assessment } & \text { of } \\
\text { logistics } & \\
\text { management meters }\end{array}$ & $\begin{array}{l}\text { Stage IV.1: Development of the } \\
\text { listing and selection of the meters } \\
\text { of the logistics management for } \\
\text { each of the modules and } \\
\text { processes in the travel agency }\end{array}$ & $\begin{array}{l}\text { Expert method, Kendall's } \\
\text { coefficient of concordance, } \\
\text { consensus method, } \\
\text { non-probabilistic sampling } \\
\text { by quotas, Cronbach's alpha } \\
\text { coefficient of reliability, } \\
\text { item-Total correlation, Fuller } \\
\text { multiattribute method, } \\
\text { satisfaction questionnaires, } \\
\text { elaboration of the fact sheet } \\
\text { of the management meters }\end{array}$ & 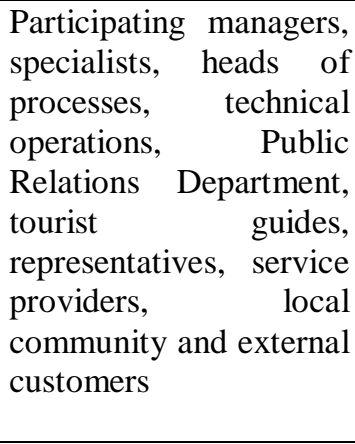 \\
\hline $\begin{array}{l}\text { Phase V: proposal o } \\
\mathrm{f} \\
\text { improvement and } \\
\text { monitoring progra } \\
\mathrm{m}\end{array}$ & $\begin{array}{lcr}\text { Stage V.1: } & \begin{array}{c}\text { Elaboration } \\
\text { improvement }\end{array} & \text { of } \\
\text { program } & \text { and } \\
\text { participation of stakeholders } & \end{array}$ & $\begin{array}{l}\text { Group work techniques to } \\
\text { develop the improvement } \\
\text { proposals corresponding to } \\
\text { each of the modules } \\
\text { identified in the research }\end{array}$ & $\begin{array}{l}\text { Management process, } \\
\text { human resources, } \\
\text { operations, economic- } \\
\text { financial, assistance and } \\
\text { representation, } \\
\text { marketing }\end{array}$ \\
\hline
\end{tabular}

\section{Results and discussion:-}

This section is the presentation and analysis of the evaluation of quantitative and qualitative measurement variables of logistics management in the wholesale travel agency: Kachay Travel Services S.A., which is located in the city of Quito, capital of Ecuador. Its main activity as established in the Ecuadorian Tourism Law, is to plan, develop and organize all kinds of national and international tourist packages and services to be offered to retail travel agencies. It also offers among other services, the training and advising to other tourist companies, university students, and 
institutions of technical and higher education, which have in their curriculum of study, the career of tourism and ecotourism, detailed in phase IV, on the basis of the performance of the different modules associated with the processes already identified.

In this sense, the proposal of measurement variables, which will allow to establish the necessary relationship between sustainable and responsible action of the travel agency and the logistics management of the service delivery processes respectively. In the literature review, only two publications have been identified that refer to this issue of proposal of indicators for the measurement of the corporate social responsibility (Vives, 2011) and model of corporate social responsibility indicators for the transport and logistics sector (González, 2012).

When processing the information gathered from the questionnaires applied to the wholesale travel agency: Kachay travels Services S.A., and its subsequent statistical processing through the use of the software SPSS v. 20, the modules are sorted for the Logistics management, according to the scores given by the experts and specialists surveyed, from lowest to highest, being ordered as follows: Responsible action (3.5); information technology (3.7); logistical yields (3.8); environmental barriers (4.0); Integration of the chain (4.0); Software System (4.0); Human Capital (4.1); organization and management (4.2) and logistics concept (4.4) respectively. From the analysis of the preliminary information, it may be contended that the logistics management in the Travel Agency is evaluated as satisfactory, by obtaining an average score of 4.0; but it must be pointed out that the modules responsible action; Information Technology and Logistical yields, they get a rating below the average, which indicates, that present an acceptable behavior in terms of sustainable and responsible action.

The Kendall's coefficient obtained has a value of 0.88 , which shows that there is agreement between the judgments issued by the experts, who according to their own criteria established the ordering of each of the modules in the Travel Agency, According to the frequency shown in the different positions, the modules were ordered as: Human capital (1); Responsible action (2); organization and management (3); integration of the chain (4); Logistics concept (5); Logistical yields (6); Information technology (7); Software system (8), finally, environmental barriers (4.0) in that order established by the consulted specialists.

Fuller's modified triangle multi attribute method (Frías, et al., 2008), is used after calculating the frequencies for the ordering of each of the modules, in order to determine the priorities of each modules.to do this, a pair ranking matrix is formalized between each one of the modules, assigning a value one to the module of higher priority, and zero to the opposite, to finally obtain the modules of higher priority according to the expert judgments and specialists consulted, resulting the following priorities: Human capital (0.20); Responsible action (0.13); Organization and management (0.18); Integration of the chain (0.16); Logistics concept (0.02); Logistical yields (0.11); Information technology (0.09); Software system (0.07), finally, environmental barriers (0.04). It can be seen the highest priority modules correspond to the modules of human capital, organization and management, finally Module 9 of responsible action.

Subsequently, the evaluation of the measurement variables is carried out according to their measurement criterion and evaluation scale. After having the quantitative value of the indicators and their location on their qualitative scale, all the scales of the indicators are homogenized on a Likert-type scale from very unsatisfactory $(\mathrm{MI}=1)$ to very satisfactory $(\mathrm{MS}=5)$ for module 09 Responsible action. For the rest of the modules, the Likert scale is classified from very unfavorable $(\mathrm{MD}=1)$ to very favorable $(\mathrm{MF})$ for the modules corresponding to logistics concept, organization and management, information technology, software system, integration of the chain, human capital, logistical yields, finally, environment barriers in that order of analysis, Chart 2.

Chart 2:- Calculation of the measurement variables of the logistics management corresponding to each of the modules and processes identified for the Travel Agency.

\begin{tabular}{|l|l|l|c|c|}
\hline \multicolumn{1}{|c|}{ Module } & Processes & \multicolumn{1}{|c|}{ Measurement variables } & $\begin{array}{c}\text { Quantitative } \\
\text { value }\end{array}$ & $\begin{array}{c}\text { Qualitative } \\
\text { evaluation }\end{array}$ \\
\hline $\begin{array}{l}\text { Logistics } \\
\text { concept }\end{array}$ & Management & $\begin{array}{l}\text { I 1: Management based on logistical } \\
\text { programms }\end{array}$ & 4,5 & Favorable \\
\cline { 2 - 5 } & Marketing & $\begin{array}{l}\text { I 2: Existence of quality and cost requirements } \\
\text { in logistical processes. }\end{array}$ & 4,1 & Favorable \\
\hline $\begin{array}{l}\text { Organization and } \\
\text { Management }\end{array}$ & Marketing & $\begin{array}{l}\text { I 3: It is performed demand forecast and } \\
\text { market research }\end{array}$ & 4,1 & Favorable \\
\hline
\end{tabular}




\begin{tabular}{|c|c|c|c|c|}
\hline $\begin{array}{l}\text { Information } \\
\text { technology }\end{array}$ & Management & $\begin{array}{l}\text { I 4: Level of integrated processing of } \\
\text { information systems in logistics. }\end{array}$ & 3,9 & Aceptable \\
\hline Software system & Management & $\begin{array}{l}\text { I 5: Level of integration of information } \\
\text { management systems. }\end{array}$ & 4,1 & Favorable \\
\hline \multirow[t]{4}{*}{$\begin{array}{l}\text { Integration of the } \\
\text { chain }\end{array}$} & \multirow[t]{2}{*}{ Marketing } & $\begin{array}{l}\text { I 6: Level of support with contracts of the } \\
\text { alliances established with borrowers. }\end{array}$ & 4,3 & Favorable \\
\hline & & $\begin{array}{l}\text { I 7; Degree of personalization of customer } \\
\text { service }\end{array}$ & 4,0 & Favorable \\
\hline & \multirow[t]{2}{*}{ Operations } & $\begin{array}{l}\text { I 8: Joint improvement programs with } \\
\text { service providers }\end{array}$ & 4,2 & Favorable \\
\hline & & $\begin{array}{l}\text { I 9: Level of implementation of the } \\
\text { certification program to service providers }\end{array}$ & 3,7 & Aceptable \\
\hline \multirow[t]{2}{*}{ Human capital } & \multirow[t]{2}{*}{$\begin{array}{l}\text { Human } \\
\text { Resources }\end{array}$} & $\begin{array}{l}\text { I 10: Degree of staff participation in logistics } \\
\text { management training programs }\end{array}$ & 3,8 & Acceptable \\
\hline & & $\begin{array}{l}\text { I 11: Domain and application by the internal } \\
\text { customer of objectives, policies, rules and } \\
\text { procedures for logistics management }\end{array}$ & 3,9 & Acceptable \\
\hline \multirow[t]{4}{*}{ Logistical yields } & \multirow[t]{2}{*}{ Marketing } & $\begin{array}{l}\text { I 12: Frequent analysis of the level of } \\
\text { customer service and providers. }\end{array}$ & 4,2 & Favorable \\
\hline & & $\begin{array}{l}\text { I 13: External customer satisfaction rate } \\
\text { Criterion of measurement: : Number of } \\
\text { satisfied customers/ total number of } \\
\text { clients*100 }\end{array}$ & 0,86 & Favorable \\
\hline & \multirow[t]{2}{*}{$\begin{array}{l}\text { Economic- } \\
\text { financial }\end{array}$} & $\begin{array}{l}\text { I 14: Cost/profit rate in service delivery. } \\
\text { Criterion of measurement: Utility/ Total } \\
\text { Income }\end{array}$ & 0,16 & Acceptable \\
\hline & & $\begin{array}{l}\text { I 15: Compliance rate of the level of sales } \\
\text { Criterion of measurement: It is estimated the } \\
\text { real value of sales/ planned value of sales. }\end{array}$ & 1,06 & $\begin{array}{c}\text { Very } \\
\text { favorable }\end{array}$ \\
\hline $\begin{array}{l}\text { Environmental } \\
\text { barriers }\end{array}$ & Management & $\begin{array}{l}\text { I16: Rate of implementation of the goals and } \\
\text { objectives described in the Travel Agent } \\
\text { strategic plan to mitigate the critical factors of } \\
\text { the environment }\end{array}$ & 4,2 & Favorable \\
\hline \multirow[t]{7}{*}{$\begin{array}{l}\text { Responsible } \\
\text { action }\end{array}$} & \multirow[t]{3}{*}{ Management } & $\begin{array}{l}\text { I 17: Assessment of compliance with rules, } \\
\text { resolutions and environmental strategies }\end{array}$ & 3,0 & $\begin{array}{l}\text { Unsatisfact } \\
\text { ory }\end{array}$ \\
\hline & & $\begin{array}{l}\text { I 18: Obtaining quality and environmental } \\
\text { certifications granted }\end{array}$ & 2,1 & $\begin{array}{l}\text { Unsatisfact } \\
\text { ory }\end{array}$ \\
\hline & & $\begin{array}{l}\text { I 19: Satisfaction rate of the local community } \\
\text { with the responsible action of the Travel } \\
\text { Agencies }\end{array}$ & 3,1 & Acceptable \\
\hline & Marketing & $\begin{array}{l}\text { I 20Satisfaction index of providers with the } \\
\text { responsible action of the Travel Agencies }\end{array}$ & 3,6 & Acceptable \\
\hline & \multirow[t]{3}{*}{$\begin{array}{l}\text { Human } \\
\text { Resources }\end{array}$} & $\begin{array}{l}\text { I 21: Participation rate of local community as } \\
\text { workforce } \\
\text { Criterion of measurement: Number of workers } \\
\text { in town/total number of workers in the travel } \\
\text { agency. }\end{array}$ & 0,14 & $\begin{array}{c}\text { Unsatisfact } \\
\text { ory }\end{array}$ \\
\hline & & $\begin{array}{l}\text { I 22: Index of environmental education } \\
\text { programs and activities for internal clients } \\
\text { Criterion of measurement: Number of } \\
\text { programs and environmental education } \\
\text { activities/Total programs and activities } \\
\text { performed at the travel agency for internal } \\
\text { customer training }\end{array}$ & 0,33 & Acceptable \\
\hline & & I 23: Satisfaction rate of the internal customer & 0,44 & Unsatisfact \\
\hline
\end{tabular}




\begin{tabular}{|l|l|l|l|l|}
\hline & $\begin{array}{l}\text { Criterion of measurement: Number of satisfied } \\
\text { internal customer/ Total number of internal } \\
\text { customer }\end{array}$ & ory \\
\hline
\end{tabular}

Source: adapted from Cuétara, (2010).

The analysis of the measurement variables of the logistics management corresponding to each of the modules and processes recognized for the Travel Agency, summarizes that out of a total of twenty three proposed meters, receive a qualitative assessment according to the preceding scale defined between favorable and very favorable 47.8 percent (eleven in total), evaluated with the qualification of acceptable $34.7 \%$ (eight meters), the remainder representing $17.3 \%$ (four indicators), an assessment of unsatisfactory, according to the defined qualitative scales.

From the results obtained in the evaluation of the modules, processes and measurement variables of logistics management, and completing the Phase V: Proposal for a program of improvement and follow-up, the managers of the business organization, should provide the necessary attention and elaboration of the proposal for a plan of improvement and follow-up in the short and medium term, mainly regarding to the module 09 of responsible action, and in particular, Management process, Human Capital and marketing especially, considering the following tasks:

1. To elaborate the environmental diagnosis dossier, to aim for the environmental license, which would increase an added value to the attributes related to the provision of products and services present.

2. To develop environmental education programs, related to natural resources and tourist attractions that are marketed for its product portfolio, mainly aimed at training and preparations in topics of environmental management for executives and internal customer, as a first priority.

3. To carry out a comprehensive diagnosis of natural resources and tourist attractions that make up the optional and circuits the Travel Agency sells, with the aim to develop an intensive program of conservation and preservation actions of the same, what would motivate an improvement in the external customer satisfaction, from the enjoyment of the natural and landscape values identified in each product.

4. To establish education and training groups in aspects of the logistics system, its management and development for all their internal customers with a view to acquire greater knowledge on the topic of study, on the basis of the importance that has the same today in business organizations for the improvement of the efficiency, quality and competitiveness.

5. To introduce control mechanisms over the development and improvement of their internal customers at the ending of education and training courses in the performance evaluation in order to be able to measure the impact of these programs in the work they do.

6. To diagnose the core competencies required for the internal customer that can relate and identify with the development of the theme of logistics management in areas such as: purchases, flow of information, distribution, relationship with suppliers and customers, level of service, among others.

\section{Conclusions:-}

In general, the partial implementation of the business sustainability model, the reference model of the logistics of excellence, the philosophy of the process approach and the multidimensional analysis of sustainability and the responsible action of business organizations for logistics management in travel agencies, as well as a methodological procedure, corroborating their theoretical and practical validity, all this, allow the evaluation of the logistics management from the process approach, in relation to the social, economic, environmental and technological dimensions, in addition to, they demonstrate the viability of the integration of the different proposals in travel agencies.

It was possible to confirm, based on the literature review, the little information that exists concerning the logistics models with process focus for the evaluation of products and services in business organizations, especially in travel agencies, as well as, the non-description of the procedure of a theoretical and practical nature, feasible of implementation by entities providing service to the international tourism, in order to improve and perfect its logistics management and competitiveness in the tourism sector. 


\section{References:-}

1. Acevedo, J. (2008). Modelos y estrategias de desarrollo de la logística y las redes de valor en el entorno de Cuba y Latinoamérica. (Tesis en opción a Doctor en Ciencias), ISPJAE, Ciudad de La Habana, Cuba, pp. 2730, 67-77

2. Al-Weshah, G. A., Alnsour, M. S., Al-Hyari, K., Alhammad, F., \& Algharabat, R. (2013). Electronic Networks and Relationship Marketing: Qualitative Evidence From Jordanian Travel Agencies. Journal of Relationship Marketing, 12 (4), 261-279. doi:10.1080/15332667.2013.846245

3. Anjum, M. N., Xiuchun, B., Abbas, J., Shuguang, Z., \& McMillan, D. (2017). Analyzing predictors of customer satisfaction and assessment of retail banking problems in Pakistan. Cogent Business \& Management, 4(1), 1338842. doi:10.1080/23311975.2017.1338842

4. Ballou, B., Heitger, D. L., Landes, C. E., \& Adams, M. (2006). The future of corporate sustainability reporting. Journal of Accountancy, 202(6), 65.

5. Ballesteros, DP, Ballesteros, P, and Duarte, T. (2009). Contributions of the Logistics to sustainable development. Scientia et Technica, 470. 0122-1701

6. Boysen, N., Briskorn, D., \& Emde, S. (2016). Just-in-time vehicle scheduling with capacity constraints. IIE Transactions, 48 (2), 134-145. doi:10.1080/0740817X.2015.1056390

7. Carvache, W., Torres, M., \& Carvache, M. (2017). Análisis del perfil y satisfacción del turista que visita montañita-Ecuador. Cuadernos de Turismo (39), 113-129.

8. Chen, C.-T. (2014). A MODEL-BASED DIRECT ADAPTIVE PI CONTROLLER FOR NONLINEAR PROCESS CONTROL. Chemical Engineering Communications, $201 \quad$ (9), $1148-1172$. doi:10.1080/00986445.2013.803077

9. Chiang, A.-H., Chen, W.-H., \& Wu, S. (2015). Does high supply chain integration enhance customer response speed? The Service Industries Journal, 35(1-2), 24-43. doi:10.1080/02642069.2014.979406

10. Cuétara, Y (2010). Evaluación de la sostenibilidad empresarial a partir de la gestión logística en Agencias de Viajes. Tesis en Opción al Título de Máster en Gestión Turística. Universidad de Matanzas.

11. Cuétara, L. (2017) Modeling with multidimensional approach for the management of tourism competences. Baños de Agua Santa, Ecuador. CIUM '2017, VIII International Scientific Convention of the University of Matanzas. XI International Meeting of Business Sciences and Tourism, $26 \mathrm{p}$.

12. Coavas, F. A., \& Amézquita, J. A. A. (2011). El modelo Scor (Supply Chain Operations Reference Model) aplicado a la cadena de suministro de empresas del sector comercio: caso droguerias Megaexpress. Doctoral dissertation, Universidad de Cartagena.

13. Espinosa, DV. (2010). Análisis y propuesta de un modelo de gestión deresponsabilidad social empresarial caso: empresas ecuatorianas comprometidas con RSE. Tesis en opción a Maestría en Dirección de Empresas. Universidad Andina Simón Bolívar, Sede Ecuador. Quito, 99 p.

14. Epstein, M., Alberto, S., \& Mantilla, S. A. (2009). Sostenibilidad empresarial. Bogota. Ecoe Ediciones.; 1a. ed. $306 \mathrm{p}$.

15. Geraldino, L. F., Lasprilla, S. A., Arango, M., \& Escarria, M. V. R. (2012). Diseño de un modelo de responsabilidad social empresarial en una empresa de consultoría a traves de la aplicación del mercadeo social. Dimensión empresarial, 10(2), 54-69.

16. Feitó, M., Cespón, R., \& Rubio, M. A. (2016). Modelos de optimización para el diseño sostenible de cadenas de suministros de reciclaje de múltiples productos. Ingeniare. Revista chilena de ingeniería, 24(1), 135-148.

17. Fredriksson, A., \& Johansson, E. (2009). Integrating logistics into the outsourcing process. International Journal of Logistics Research and Applications, 12(4), 281-298. doi:10.1080/13675560903076149

18. Frías R, González, M and Cuétara, L. (2008). Herramientas de Apoyo a la Solución de Problemas no Estructurados en Empresas Turísticas En. Matanzas, Cuba. Editorial Universitaria. ISBN 978-959-16-0941-0.

19. Garcia, T. I. B, López, R. R, Iniesta, A. A, González, J. R, \& Ávila, J. J. G. (2016). Factores logísticos que inciden en el aumento de la competitividad de las PyMES: una revisión de literatura. . CULCyT. (56).

20. Gómez, M. and Acevedo, JA. (1996) Sistemas logísticos. Ediciones Díaz Santos, Ciudad de La Habana.

21. González, JA. (2016). Contratación logística en Colombia: implementación de un operador logístico integral. Avantel, SAS. Semestre Económico.

22. Govindan, K. (2013). Vendor-managed inventory: a review based on dimensions. International Journal of Production Research, 51(13), 3808-3835. doi:10.1080/00207543.2012.751511

23. Hernández, L., \& Hernández, E. (1998). La naturaleza, actividad y clasificación de las agencias de viaje. Cuadernos de Turismo(1), 73-90. 
24. Ivanov, D., Sokolov, B., \& Raguinia, E. A. D. (2014). Integrated dynamic scheduling of material flows and distributed information services in collaborative cyber-physical supply networks. International Journal of Systems Science: Operations \& Logistics, 1(1), 18-26. doi:10.1080/00207721.2013.879226

25. Kandampully, J., \& Promsivapallop, P. (2006). Service Networks: A Framework to Match Customer Needs, Service Offer, and Operational Activities. Journal of Hospitality \& Leisure Marketing, 13(3-4), 103-119. doi:10.1300/J150v13n03_06

26. Kandampully, J., \& Suhartanto, D. (2003). The Role of Customer Satisfaction and Image in Gaining Customer Loyalty in the Hotel Industry. Journal of Hospitality \& Leisure Marketing, 10(1-2), 3-25. doi:10.1300/J150v10n01_02

27. Law, R., Law, A., \& Wai, E. (2002). The Impact of the Internet on Travel Agencies in Hong Kong. Journal of Travel \& Tourism Marketing, 11(2-3), 105-126. doi:10.1300/J073v11n02_06

28. Liu, Y., Pu, B., Guan, Z., \& Yang, Q. (2016). Online Customer Experience and Its Relationship to Repurchase Intention: An Empirical Case of Online Travel Agencies in China. Asia Pacific Journal of Tourism Research, 2l(10), 1085-1099. doi:10.1080/10941665.2015.1094495

29. Montero Muradas, I., \& Oreja Rodríguez, J. R. (2010). Benchmarking interno en una central de compras de agencias de viajes. Cuadernos de Turismo(26), 177-199.

30. ISO 9001:2015. Quality management systems -- Requirements. https://www.iso.org/standard/46486.html

31. Ortega Martínez, E., Rodríguez Herráez, B., \& Lévy-Mangin, J.-P. (2008). Percepción de los Servicios de Apoyo en el Sector Hotelero. Un análisis internacional. Cuadernos de Turismo(21), 113-134.

32. Park, M., Kim, J. J.-Y., Kwon, K.-m., \& Yu, G. J. (2017). Process control and economic cost design for total quality management. Total Quality Management \& Business Excellence, 28(7-8), 858-878. doi:10.1080/14783363.2015.1133243

33. Pirolli, B. (2016). Travel information online: navigating correspondents, consensus, and conversation. Current Issues in Tourism, 1-7. doi:10.1080/13683500.2016.1273883

34. Ponce, M. D. (2003). Relación entre equipamiento de servicios y modelo turístico. Cuadernos de Turismo (12), 151-164.

35. Porter, M. E. (1985). Competetive advantage. New York.

36. Sablón, N, Medina, A, Acevedo, JA, \& Acevedo, AJ. (2013). Consideraciones de la planificación de productos alimenticios en una cadena de suministro comercial. Ingeniería Industrial, (3/Vol. XXXIV). 353 -362.

37. Suárez, R (1996). Modelo de evaluación del nivel de organización de la producción en empresas de la industria mecánica., ISPJAE, La Habana. Cuba

38. Ramallo, E. d. P. (2015). El guía turístico, diferencias y similitudes entre Comunidades Autónomas. Cuadernos de Turismo(35), 499-510.

39. Ruiz, J. L. (2013). Diseño de modelo de responsabilidad social empresarial en pyme constructora araucana. Doctoral dissertation, Universidad Nacional de Colombia-Sede Manizales.

40. Sustainability Reporting Standards. (2016). Consolidated set of GRI Sustainability Reporting Standards. https://www.globalreporting.org/standards.

41. Thai, V. V. (2013). Logistics service quality: conceptual model and empirical evidence. International Journal of Logistics Research and Applications, 16(2), 114-131. doi:10.1080/13675567.2013.804907. 
